\title{
Improved assay method for activity of thyroid peroxidase- catalysed coupling of iodotyrosine residues of thyroglobulin utilizing h.p.l.c. for analysis of iodothyronines
}

\author{
Takeshi OHMORI,* Osamu TARUTANI $\dagger$ and Toichiro HOSOYA* $\ddagger$ \\ *Faculty of Pharmaceutical Sciences, Chiba University, Chiba, Chiba 260, Japan, and \\ †Division of Biological Chemistry, Science University of Tokyo, Noda, Chiba 278, Japan
}

\begin{abstract}
The coupling of iodotyrosine residues of thyroglobulin (Tg) catalysed by thyroid peroxidase (TPO) has scarcely been studied with respect to the TPO of abnormal human thyroid glands. The present paper proposes a rapid and convenient assay method applicable for determining the coupling activity of a sample of less than $500 \mathrm{mg}$ from each patient's thyroid. The main characteristics of the method are as follows: (i) mitochondrial/microsomal fractions of thyroid glands were treated with sodium cholate plus trypsin, and the supernatants obtained by ultracentrifugation were directly used for the assay of coupling and peroxidase activity of TPO; (ii) the formation of iodotyrosine residues catalysed by TPO was performed by using chemically iodinated Graves'-disease Tg containing 41 iodine atoms per molecule and with a high iodotyrosine and a low iodothyronine content; (iii) newly synthesized iodothyronine residues (thyroxine, 3,5,3'-tri-iodothyronine, and 3,3',5'-tri-iodothyronine) were analysed by h.p.l.c. after hydrolysis of $\mathrm{Tg}$ with proteinases and extraction of iodothyronines with ethyl acetate.
\end{abstract}

\section{INTRODUCTION}

It is widely accepted that, in the thyroid gland, thyroid peroxidase (TPO) catalyses both iodination of tyrosine residues and coupling of iodotyrosine residues of thyroglobulin ( $\mathrm{Tg})$. The peroxidase activity of human microsomal TPO of diseased thyroids was assayed by various methods in order to examine the relationship between thyroid diseases and quantitative and qualitative alterations of TPO in the tissues (DeGroot \& Niepomniszcze, 1977; Hosoya et al., 1985; Yoshimura et al., 1988). However, few reports have been published concerning the coupling activity of human TPO of diseased thyroids. This may be due to difficulty of obtaining a sufficient amount of purified human TPO from each diseased thyroid and the lack of a sensitive assay system. Fairly recently, Sugawara (1985) proposed an assay method for coupling activity of human TPO employing $\mathrm{Tg}$ with a low thyroid-hormone content and partially purified human TPO of diseased thyroids. Although his method did indeed increase the sensitivity of the coupling assay and eliminated, to some extent, the effect of contamination of $\mathrm{Tg}$ and other interfering materials, it requires a considerable amount of thyroid tissue (1-5 g). In addition, the partial-purification step of TPO in column chromatography may cause a loss of activity, and optimum conditions of chemically iodinated $\mathrm{Tg}$ used for the assay were not examined. The iodothyronines were quantified by radioimmunoassay, which requires radioiodine and long period of time, and furthermore, $T_{3}$ and $\mathrm{T}_{4}$ cannot be determined simultaneously.

Taking these facts into consideration, we have attempted to develop a more convenient method for assaying the coupling activity of human TPO; this method employs h.p.l.c. for the determination of iodothyronines, requires less tissue, takes less time and is more suitable for the routine assay of TPO in human diseased thyroid tissues.

\section{MATERIALS AND METHODS}

\section{Materials}

Human Tg was obtained from pooled Graves'-disease thyroid tissues by precipitating the soluble fraction of thyroid homogenate $(105000 \mathrm{~g}$ supernatant $)$ with $\left(\mathrm{NH}_{4}\right)_{2} \mathrm{SO}_{4}$, followed by DEAE-cellulose chromatography. The $\mathrm{Tg}$ preparation had 8.8 iodine atoms, 0.52 molecule of $T_{4}$ and 0.1 molecule of $T_{3}$ per molecule of $\mathrm{Tg}$.

Human TPO was purified from pooled Graves'-disease thyroid tissues (about $640 \mathrm{~g}$ ) by the method reported by Kohno et al. (1986). The final preparation had a 'Reinheitzahl' [ratio of the absorbance at the Soret band (413 nm for the present enzyme) to that at $280 \mathrm{~nm}$ ] of $0.19-0.26$. Porcine thyroid tissues were obtained from a local slaughterhouse and frozen at $-70^{\circ} \mathrm{C}$ until use.

The h.p.l.c. apparatus (Hitachi, Tokyo, Japan) consisted of a model-655 solvent motoring pump, model 655-0809 syringe-loading sample injector, model 638-41 variable u.v. monitor and a model 833 data processor. The octadecyl-silica $(5 \mu \mathrm{m}$ average particle diameter; Senshu Pak ODS-1151-N) column $(4.6 \mathrm{~mm} \times 150 \mathrm{~mm})$, was a product of Senshu Kagaku Co. (Tokyo, Japan). Unless otherwise stated, the mobile phase was $50 \%$ methanol/0.1\% phosphoric acid, and detection was at

Abbreviations used: MIT, 3-monoiodo-L-tyrosine; DIT, 3,5-di-iodo-L-tyrosine; $\mathrm{T}_{3}$, 3,5,3'-tri-iodo-L-thyronine; rT $\mathrm{T}_{3}$ ' 'reverse $\mathrm{T}_{3}$ ' (3,3',5'-tri-iodoL-thyronine); $\mathrm{T}_{4}$, thyroxine (3,5,3',5'-tetraiodo-L-thyronine); HRP, horseradish peroxidase; LPO, lactoperoxidase; MMI, 1-methylimidazole-2-thiol (methimazole); TPO, thyroid peroxidase; Tg, thyroglobulin; CU, unit of coupling activity; GU, guaiacol unit; IU, iodide unit.

¥ To whom correspondence and reprint requests should be sent. 
$235 \mathrm{~nm}$. The flow rate was $1.0 \mathrm{ml} / \mathrm{min}$. Stock solutions $\left(0.8 \mathrm{mM}^{-\mathrm{T}_{4}}, 0.9 \mathrm{mM}-\mathrm{T}_{3}\right.$ and $\left.1.5 \mathrm{mM}^{-\mathrm{rT}} \mathrm{T}_{3}\right)$ were made in $0.1 \mathrm{M}-\mathrm{NaOH}$ solution. From the stock solutions, standard solutions containing these compounds were made by serial dilutions with distilled water. Sample sizes varied between 2 and $60 \mathrm{ng}$ in a volume of $10 \mu \mathrm{l}$. Quantification was done on the basis of peak area calculated by the data processor of h.p.l.c. system.

\section{Chemical iodination of $\mathrm{Tg}$ with chloramine-T}

Chemical iodination of human $\mathrm{Tg}$ was performed by the Sugawara (1985) method, with a slight modification. To incorporate various amounts of iodine, a suitable concentration of chloramine- $\mathrm{T}$ was incubated with $\mathrm{Tg}$ for a constant incubation time $\left(2 \mathrm{~min}, 20^{\circ} \mathrm{C}\right)$; for example, incubation with $0.4 \mathrm{mM}$-chloramine- $\mathrm{T}$ gave $\mathrm{Tg}$ with 41 iodine atoms, starting from Tg with 8.8 iodine atoms. Proteolysis of $\mathrm{Tg}$ was usually carried out as follows. A portion $(1 \mathrm{mg})$ of $\mathrm{Tg}$ was incubated with $1.5 \mathrm{mg}$ of

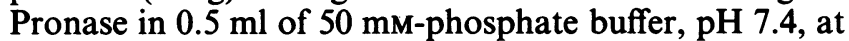
$37^{\circ} \mathrm{C}$ for $20 \mathrm{~h}$ in the dark. Then the incubation mixture was mixed with $0.05 \mathrm{ml}$ of $1 \mathrm{M}-\mathrm{HCl}$, and acidic forms of iodothyronines were extracted twice with $3 \mathrm{vol}$. of ethyl acetate. The ethyl acetate layers were combined and evaporated to remove the solvent, and the residues were dissolved in 0.5 vol. of $50 \%$ methanol $/ 0.1 \%$ phosphoric acid, followed by filtration through a Millipore filter $(0.45 \mu \mathrm{m}$ pore size). The iodothyronines in the filtrate were then analysed by h.p.l.c. as described above.

\section{Assay for peroxidase activity}

TPO activity was determined by the 'ordinary' method, using guaiacol or iodide as the second substrate, and the amount of enzyme which gave a change of $1.0 \mathrm{absorbance}$ unit/s was taken as 1 unit and expressed as guaiacol units (GU) or iodide units (IU) respectively, as described previously (Hosoya et al., 1985).

\section{Assay for coupling activity of thyroid microsomal TPO}

Homogenization and fractionation of diseased-thyroid tissues were performed by the ordinary method (Hosoya et al., 1985), with slight modifications. Frozen thyroid tissues were thawed and cut into thin slices. The slices were washed several times with cold saline $(0.9 \% \mathrm{NaCl})$ and minced with scissors. The tissues (about $500 \mathrm{mg}$ ) were homogenized in $10 \mathrm{ml}$ of 'homogenizing buffer' (20 mM-Tris/HCl, pH 7.4, containing $0.25 \mathrm{M}$-sucrose, $100 \mathrm{~mm}-\mathrm{KCl}, 40 \mathrm{~mm}-\mathrm{NaCl}$ and $10 \mathrm{~mm}-\mathrm{MgCl}_{2}$ ) with an Ultra-Turrax homogenizer at $50 \mathrm{~V}$ for $15 \mathrm{~s}$ and further homogenized with a Potter-Elvehjem-type Teflon-pestle homogenizer with ten strokes at $1200 \mathrm{rev}$./ $\min$. The homogenate was centrifuged at $700 \mathrm{~g}$ for $10 \mathrm{~min}$ and the sediment was further suspended in $2 \mathrm{ml}$ of the same buffer, followed by centrifugation at $700 \mathrm{~g}$ for $10 \mathrm{~min}$. The supernatants were combined and centrifuged at $105000 \mathrm{~g}$ for $60 \mathrm{~min}$ to precipitate the intracellular particulate fraction, which is hereafter referred to as 'microsomes'. The microsomes were suspended in $2.5 \mathrm{ml}$ of 'homogenizing buffer', followed by centrifugation at $105000 \mathrm{~g}$ for $60 \mathrm{~min}$ to eliminate contaminated proteins. The resulting final precipitates were suspended in $0.5 \mathrm{ml}$ of 'homogenizing buffer', after which the mixture was incubated at $37^{\circ} \mathrm{C}$ for $60 \mathrm{~min}$ in the presence of cholate (final concn. $7 \mathrm{mg} / \mathrm{ml}$ ) and trypsin [final concn, 50 'BAEE' (benzoylarginine ethyl ester) units/mg of protein in the suspension]. After incubation, the mixture was centrifuged at $105000 \mathrm{~g}$ for $60 \mathrm{~min}$ and an aliquot of the resulting supernatant was subjected to peroxidase assay and coupling assay. The coupling-assay system contained, in a total volume of $0.5 \mathrm{ml}$, chemically iodinated $\mathrm{Tg}$ (1 $\mathrm{mg})$, glucose (15 mM), DIT $(0.1 \mathrm{~mm})$, glucose oxidase $(0.025 \mu \mathrm{g})$ and solubilized microsomes $(0.05-$ $1.0 \mathrm{mGU})$. The reaction was initiated by adding glucose oxidase and incubation was carried out $37^{\circ} \mathrm{C}$ for $15 \mathrm{~min}$. At the end of the reaction, $20 \mu 1$ of $50 \mathrm{~mm}-\mathrm{MMI}$ was added to the reaction mixture, which was immediately chilled on ice. The mixture was then mixed with $50 \mu \mathrm{l}$ of a Pronase solution $(30 \mathrm{mg} / \mathrm{ml})$ and incubated for $20 \mathrm{~h}$ at $37^{\circ} \mathrm{C}$, followed by extraction with ethyl acetate. A correction for the extraction was made since the efficiency in these experiments was found to be usually $90 \%$. One unit of coupling activity (CU) was defined as the formation of one iodothyronine residue/min per mol of $\mathrm{Tg}$ per min under these conditions. Protein-based specific activity was expressed as $\mathrm{CU} / \mathrm{mg}$ of protein.

\section{Determination of haem content in peroxidase solutions}

The concentration of HRP was determined by measuring the absorbance at $403 \mathrm{~nm}$ and using an $\epsilon_{403}$ value of $1.02 \times 10^{5} \mathrm{M}^{-1} \cdot \mathrm{cm}^{-1}$ (Aibara et al., 1982). The concentration of LPO was determined by using an $\epsilon_{413}$ value of $1.14 \times 10^{5} \mathrm{M}^{-1} \cdot \mathrm{cm}^{-1}$ (Ohtaki et al., 1985). The concentration of TPO was estimated on the basis of the cyanide difference spectrum as described previously (Hosoya \& Morrison, 1967), except that an $\epsilon$ value of $1.16 \times 10^{5} \mathrm{M}^{-1} \cdot \mathrm{cm}^{-1}$ was employed on the basis of experiments using purified human TPO (T. Hosoya, unpublished work).

\section{Determination of iodothyronines by ion-exchange chromatography and radioimmunoassay}

The method of analysis of iodothyronines by ionexchange chromatography was as described previously (Sorimachi \& Ui, 1974). The radioimmunoassay was performed at the Teijin Bio-Science Laboratory (Tokyo) using a radioimmunoassay kit (T-3-RIABEAD and T-4·RIABEAD; Dainabot Co.).

\section{RESULTS}

\section{Separation of iodothyronines by h.p.l.c.}

A mixture of authentic iodothyronines $\left(T_{4}, T_{3}\right.$ and $\left.\mathrm{rT}_{3}\right)$ was run on an octadecyl-silica column under various conditions to establish an elution system suitable for analysis. When a $60 \%$-methanol $/ 0.1 \%-\mathrm{H}_{3} \mathrm{PO}_{4}$ eluant was used as described by Hearn et al. (1978), the separation of iodothyronines was found to be insufficient in our column because of too rapid an elution, as shown in Fig. 1(a)(ii). When the methanol concentration was reduced to $50 \%$, however, an adequate separation of these three authentic iodothyronines was attained (Fig. $1 a$,ii).

Then, using the eluant, variable wavelengths between 225 and $254 \mathrm{~nm}$ were tested for detection. The maximum sensitivity was found at $225 \mathrm{~nm}$, where the absorbance peaks of $T_{4}$ and $T_{3}$ are observed, but the absorbance tended to suffer interference from the absorbance of methanol itself. The detection at $210 \mathrm{~nm}$ was more sensitive, as shown by Hearn et al. (1978), but it has a shortcoming in that a strong optical absorption of peptide appears in the u.v. region. Thus we decided to use $235 \mathrm{~nm}$ for detection in the routine assay. The relative 

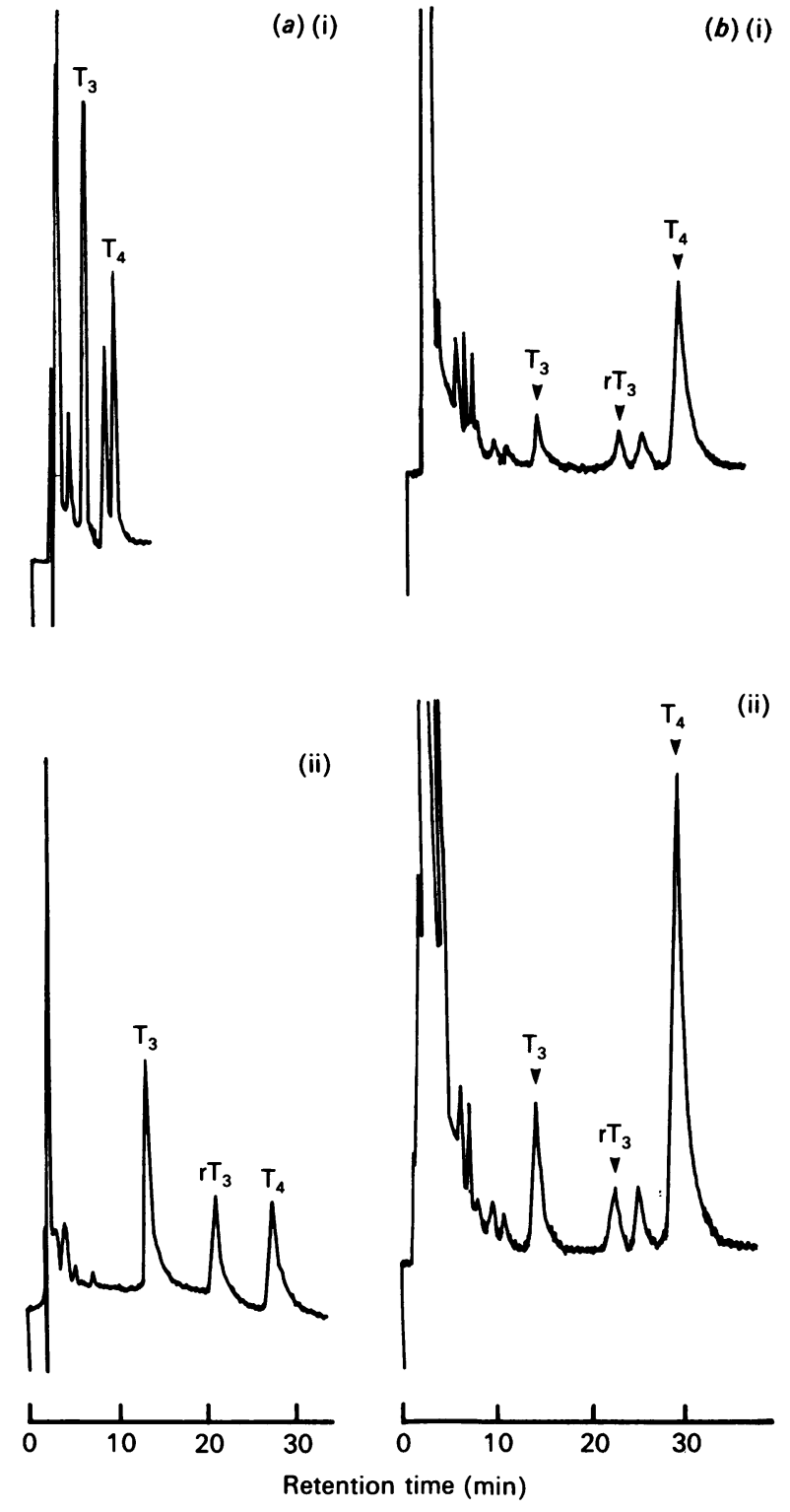

Fig. 1. Separation of iodothyronines by reversed-phase h.p.l.c.

(a) Effect of methanol concentration on the separation of authentic iodothyronines. A portion $(10 \mu \mathrm{l})$ of a mixture of authentic iodothyronines $\left(\mathrm{T}_{4}, \mathrm{~T}_{3}\right.$ and $\mathrm{rT}_{3}$; each $\left.2 \mu \mathrm{M}\right)$ was injected on to an octadecyl-silica column $(4.6 \mathrm{~mm} \times 150 \mathrm{~mm})$ and eluted at the flow rate of $1.0 \mathrm{ml} / \mathrm{min}$. The mobile phase was $60 \%$ methanol $/ 0.1 \% \mathrm{H}_{3} \mathrm{PO}_{4}$ in $(a, \mathrm{i})$ and $50 \%$ methanol $/ 0.1 \% \mathrm{H}_{3} \mathrm{PO}_{4}$ in $(a, \mathrm{ii})$. The wavelength used for detection was $235 \mathrm{~nm}$. Calculation of the peak area was made by the data processor of the h.p.l.c. system. (b) Typical h.p.l.c. patterns for extracts from hydrolysed human $\mathrm{Tg}(b, \mathrm{i})$. A $1 \mathrm{mg}$ portion of chemically iodinated Graves'-disease $\mathrm{Tg}$ containing $0.80 \%$ iodine (41 atoms/ molecule) was digested with Pronase $(3 \mathrm{mg} / \mathrm{ml})$ for $20 \mathrm{~h}$ at $37^{\circ} \mathrm{C}$, in a total volume of $0.5 \mathrm{ml}$, and the material extracted with ethyl acetate was applied on to the octadecyl-silica column as described in the Materials and methods section. $(b$, ii) A $1 \mathrm{mg}$ portion of the $\mathrm{Tg}$ mentioned above (41 iodine atoms/molecule) was incubated with human TPO $(6.4 \mathrm{pmol} / \mathrm{ml})$ at $37^{\circ} \mathrm{C}$ for $20 \mathrm{~min}$ in the presence of glucose $(15 \mu \mathrm{mol} / \mathrm{ml})$, DIT $(5 \mathrm{nmol} / \mathrm{ml})$, glucose oxidase $(0.05 \mu \mathrm{g} / \mathrm{ml})$ in a total volume of $0.5 \mathrm{ml}$ at $37^{\circ} \mathrm{C}$ for $20 \mathrm{~min}$. Digestion with Pronase $(3 \mathrm{mg} / \mathrm{ml})$ and application of extracts to the column was performed as described in $(b, i)$. area of peak regions was automatically determined by the data processor of our h.p.l.c. system. When standard solutions of iodothyronines at various concentrations were examined by these procedures, a linear relationship was obtained between the relative values of peak areas and the amount of iodothyronines (results not shown).

\section{Enzymic hydrolysis of $\mathrm{Tg}$ and determination of released iodothyronines}

In order to quantify iodothyronines in $\mathrm{Tg}$ by h.p.l.c., Tg should first be hydrolysed with proteinase, followed by extraction with organic solvent. Many methods were tested, and those finally adopted are described in the Materials and methods section.

Figs. $1(b, i)$ and $1(b$, ii) show typical h.p.l.c. patterns of iodothyronines extracted with ethyl acetate from hydrolysates of chemically iodinated Graves'-disease Tg (41 iodine atoms/mol of $\mathrm{Tg}$ ) and of the $\mathrm{Tg}$ after treatment with TPO and $\mathrm{H}_{2} \mathrm{O}_{2}$ respectively. Under the conditions used, $\mathrm{T}_{3}, \mathrm{rT}_{3}$ and $\mathrm{T}_{4}$ could be sufficiently separated as peaks at 15, 23 and $30 \mathrm{~min}$. In addition to these peaks, a small peak, which migrates faster $(26 \mathrm{~min})$ than $T_{4}$, always appeared, but identification of this peak has not yet been made. Large peaks near the front can probably be ascribed to iodotyrosines and other hydrophobic amino acids, such as tryptophan (Alexander \& Nishimoto, 1979). These large peaks show a considerable tailing and are raised slightly from the baseline, but the data processor of h.p.l.c. apparatus can automatically measure the area of each peak as described above. Table 1 shows that the values for $\mathrm{T}_{4}$ of Graves'-disease thyroids determined on the basis of the calibration curves correlated well with those obtained by analysis of ion-exchange chromatography. However, our data for $T_{3}$ were slightly higher than those of the latter analysis, and both our $\mathrm{T}_{4}$ and $T_{3}$ values were considerably higher than those obtained by radioimmunoassay.

\section{Determination of coupling activity utilizing chemically iodinated $\mathrm{Tg}$ as the substrate}

In the assay for coupling activity of human TPO of Graves'-disease thyroid, Sugawara (1985) employed, as the substrate, human $\mathrm{Tg}$ with low iodothyronine, but high iodotyrosine, content. However, the optimum iodine content of $\mathrm{Tg}$ and the optimum amounts of $\mathrm{H}_{2} \mathrm{O}_{2}$ generating system and an activator, DIT, were not examined. In preliminary experiments we found that the optimum concentrations of glucose oxidase and DIT are $0.05 \mu \mathrm{g} / \mathrm{ml}$ and $0.1 \mathrm{~mm}$ respectively. In addition, as shown in Fig. 2, an increase in the number of newly formed iodothyronine residues (mostly $T_{4}$ ) was found to depend on the number of iodine atoms in the $\mathrm{Tg}$ used (Fig. 2, $\square$ ), the value levelling off at 41 atoms of iodine per $\mathrm{Tg}$ molecule. From these observations the assay system for the coupling reaction was constructed as described in the Materials and methods section. Under the conditions used, it was confirmed that the formation of iodothyronines on $\mathrm{Tg}$ with 41 iodine atoms linearly increases with incubation time over the range 2-20 min (results not shown).

When the production of iodothyronines in $20 \mathrm{~min}$ under the conditions was measured over the range 1$12 \mathrm{nM}$-TPO, it was found that the formation of iodothyronine residues increased with increasing TPO, levelling off at 6 nM-TPO (Fig. 3). This Figure also shows, 
Table 1. Comparison of determination of iodothyronines of Graves'-disease Tg by h.p.l.c. with those by ion-exchange chromatography (I.c.) and radioimmunoassay (R.i.a.)

Values in parentheses are relative ones, taking the value by h.p.l.c. as 100. Abbreviation: ND, not detected.

\begin{tabular}{|c|c|c|c|c|c|}
\hline \multirow[b]{2}{*}{ Tg sample } & \multirow{2}{*}{$\begin{array}{c}\text { Iodine content of } \\
\operatorname{Tg}(\%)\end{array}$} & \multirow[b]{2}{*}{ Procedure } & \multicolumn{3}{|c|}{ Content $(\mathrm{mol} / \mathrm{mol}$ of $\mathrm{Tg})$} \\
\hline & & & $T_{4}$ & $\mathrm{~T}_{3}$ & $\mathrm{rT}_{3}$ \\
\hline \multirow[t]{3}{*}{1} & 0.16 & H.p.l.c. & $0.815(100)$ & $0.139(100)$ & 0.095 \\
\hline & & I.c. & $0.715(88)$ & $0.091(65)$ & ND \\
\hline & & R.i.a. & $0.569(71)$ & $0.069(50)$ & ND \\
\hline \multirow[t]{3}{*}{2} & 0.18 & H.p.l.c. & $0.825(100)$ & $0.128(100)$ & 0.090 \\
\hline & & I.c. & $0.905(110)$ & $0.097(76)$ & ND \\
\hline & & R.i.a. & $0.733(89)$ & $0.076(59)$ & ND \\
\hline \multirow[t]{2}{*}{3} & 0.16 & H.p.l.c. & $0.705(100)$ & $0.125(100)$ & 0.055 \\
\hline & & $\begin{array}{l}\text { I.c. } \\
\text { R.i.a. }\end{array}$ & $0.680(96)$ & $0.080(64)$ & ND \\
\hline \multirow[t]{3}{*}{4} & 0.17 & H.p.l.c. & $0.835(100)$ & $0.124(100)$ & 0.075 \\
\hline & & I.c. & $0.860(103)$ & $0.142(115)$ & ND \\
\hline & & R.i.a. & $0.412(49)$ & $0.042(34)$ & ND \\
\hline \multirow[t]{3}{*}{5} & 0.16 & H.p.l.c. & $0.675(100)$ & $0.119(100)$ & 0.070 \\
\hline & & I.c. & $0.750(111)$ & $0.090(76)$ & ND \\
\hline & & R.i.a. & - & - & - \\
\hline \multirow{3}{*}{ Mean ts E M } & 0.12 & H.p.l.c. & $0.580(100)$ & $0.089(100)$ & 0.055 \\
\hline & & I.c. & $0.570(98)$ & $0.073(82)$ & ND \\
\hline & & R.i.a. & $0.483(83)$ & $0.041(46)$ & ND \\
\hline Mean \pm S.E.M. & & H.p.l.c. & $(100)$ & (100) & \\
\hline & & I.c. & $(101 \pm 3.3)$ & $(80 \pm 7.0)$ & \\
\hline & & R.i.a. & $(73 \pm 7.7)$ & $(47 \pm 4.5)$ & \\
\hline
\end{tabular}

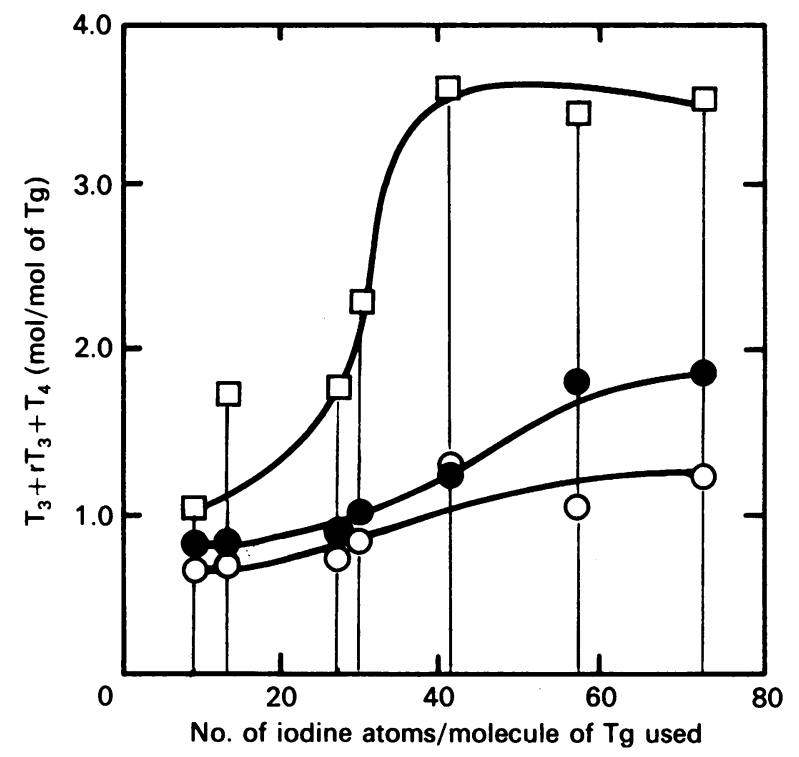

Fig. 2. Formation of iodothyronine residues of $\mathrm{Tg}$ as a function of iodine content of chemically iodinated $\mathrm{Tg}$

$\mathrm{Tg}$ preparations with various iodine contents were prepared as described in the Materials and methods section. With these Tgs the coupling reaction was carried out for $20 \mathrm{~min}$ at $37^{\circ} \mathrm{C}$ in a reaction mixture that contained, in a total volume of $0.5 \mathrm{ml}$, TPO $(13.5 \mathrm{pmol} / \mathrm{ml})$, glucose $(15 \mu \mathrm{mol} / \mathrm{ml})$, glucose oxidase $(0.05 \mu \mathrm{g} / \mathrm{ml})$, DIT $(5 \mathrm{nmol} /$ $\mathrm{ml})$ and chemically iodinated $\mathrm{Tg}(2 \mathrm{mg} / \mathrm{ml})$. The proteins were then hydrolysed with Pronase $(3 \mathrm{mg} / \mathrm{ml})$ at $37^{\circ} \mathrm{C}$ for $20 \mathrm{~h}$, and the material extracted with ethyl acetate was applied on to the h.p.l.c. column to determine iodothyronines. As controls, the $\mathrm{Tg}$ preparations incubated without $\mathrm{TPO}$, and the $\mathrm{Tg}$ preparations alone, were hydrolysed to determine iodothyronines in a similar manner. Iodo-

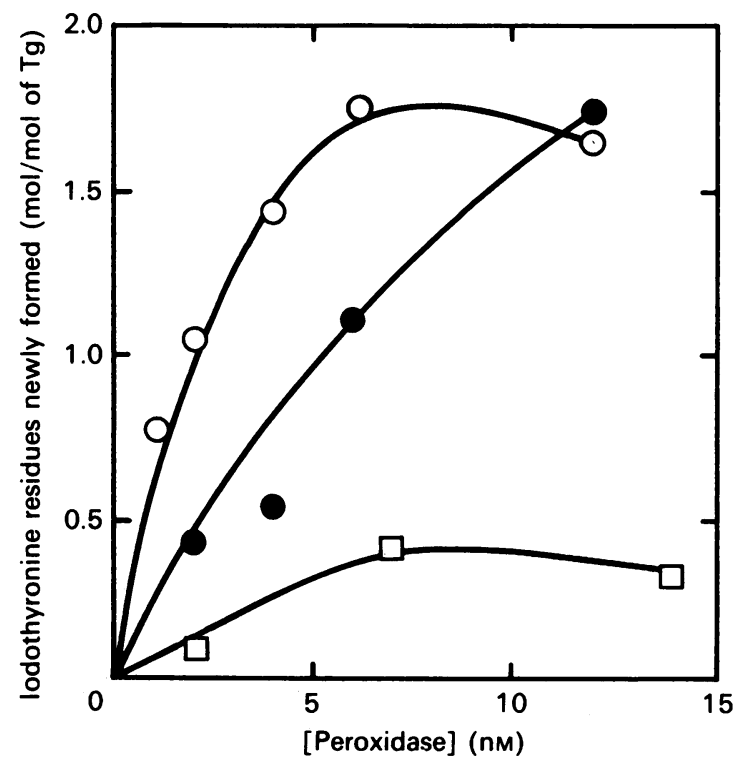

Fig. 3. Comparison between catalytic efficiencies of TPO, LPO and HRP in the coupling reaction

The reaction mixture consisted of chemically iodinated $\mathrm{Tg}$ $(2 \mathrm{mg} / \mathrm{ml})$, glucose $(15 \mu \mathrm{mol} / \mathrm{ml})$, DIT $(5 \mathrm{nmol} / \mathrm{ml})$, glucose oxidase $(0.05 \mu \mathrm{g} / \mathrm{ml})$ and peroxidase $(1-14 \mathrm{pmol} / \mathrm{ml})$, in a total volume of $\mathrm{C.5 \textrm {ml }}$. After incubation at $37^{\circ} \mathrm{C}$ for $20 \mathrm{~min}$, newly formed iodothyronines $\left(\mathrm{T}_{4}+\mathrm{T}_{3}+\mathrm{rT}_{3}\right)$ were determined as described in Fig. 2. O, TPO; , LPO; $\square$, HRP.

thyronine $\left(\mathrm{T}_{4}+\mathrm{T}_{3}+\mathrm{rT} \mathrm{T}_{3}\right)$ contents were expressed as mol/ mol of Tg. $\square$, After incubation with all constituents; 0 , after incubation without TPO; $\bigcirc$, before incubation. 
for comparison, the results obtained using LPO and HRP under the same conditions. It is noteworthy that the formation of iodothyronine residues (mostly $\mathrm{T}_{4}$ ) by LPO was linear over the range of 2-12 nM-LPO, being always below the level of TPO, and that only extremely small amounts of compounds were synthesized by HRP under the conditions used. From the data obtained with less than 6 nM-peroxidase shown in Fig. 3, the coupling activities of the three peroxidases were calculated to be 33.7, 15.1 and 3.27 CU/nmol of haem of TPO, LPO and HRP respectively. Thus TPO was found to be the most efficient enzyme in the coupling reaction under these conditions, although a previous report (Taurog et al., 1974) demonstrated that TPO and LPO had almost equal efficiency in the reaction.

In a previous paper concerning the assay for peroxidase activity (Hosoya et al., 1985), we measured the peroxidase activity of thyroid microsomes after solubilization with cholate $7 \mathrm{mg} / \mathrm{ml}$. It was found, however, that the formation of iodothyronines catalysed by cholate-treated microsomal TPO proceeded only for about $5 \mathrm{~min}$, thereafter diminishing. Although the cause of such an abrupt fall in the activity is not known, it may be due to deiodination or a degradation of the iodothyronines. While tracing the cause, it was fortuitously found that addition of trypsin during the solubilization gave a time course comparable with that of purified TPO. Although it was not clear why the use of trypsin prevented degradation during the formation of iodothyronines, we decided to employ trypsin in addition to cholate for solubilization of microsomal TPO as described in the Materials and methods section.

When TPO solubilized with trypsin plus cholate from microsomes was used for the coupling-assay system, the formation of iodothyronines was found to increase linearly with increasing amounts of TPO only over the range of $0.4-2.0 \mathrm{mGU} / \mathrm{ml}$ (Fig. 4). Since excess TPO actually diminishes the formation of iodothyronines, the amount of microsomal TPO used for the assay should not exceed $1 \mathrm{mGU} / \mathrm{ml}$. In addition, the microsomal fraction was found to contain endogenous $\mathrm{Tg}$, albeit in very small amounts (usually below $0.05 \mathrm{mg}$ of $\mathrm{Tg}$ per $\mathrm{mg}$ of microsomal protein). Therefore, in each determination, the newly formed iodothyronines were obtained by subtracting the amount of iodothyronines found in control tubes in which only the glucose-glucose oxidase system was omitted.

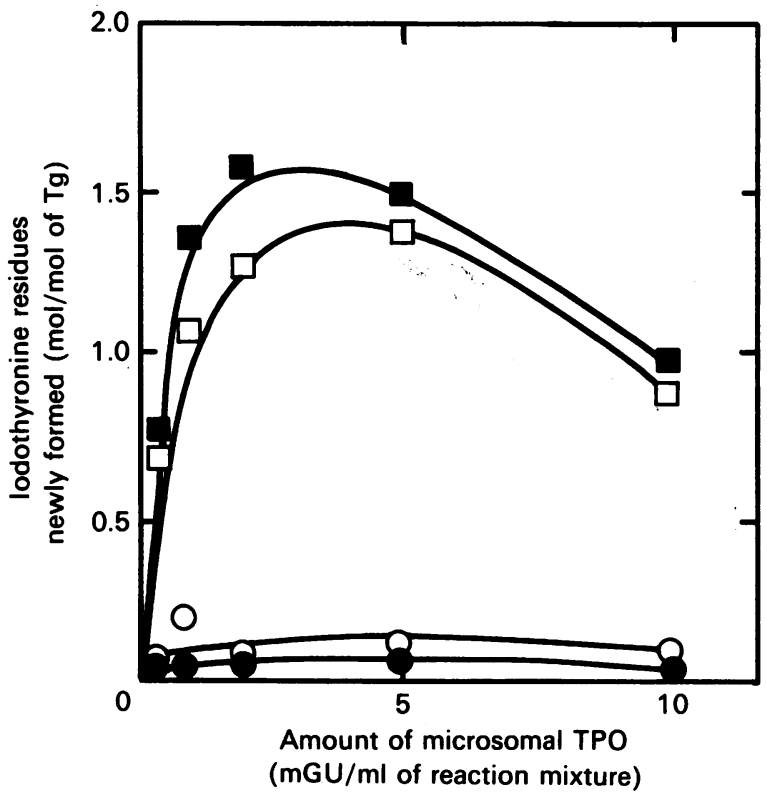

Fig. 4. Formation of iodothyronine residues of $\mathrm{Tg}$ as a function of porcine microsomal TPO

The coupling reaction and determination of iodothyronines was performed as described in the text. $\mathrm{O}, \mathrm{T}_{3}$; $0, \mathrm{rT}_{3} ; \square, \mathrm{T}_{4} ; \square, \mathrm{T}_{3}+\mathrm{rT}_{3}+\mathrm{T}_{4}$.

\section{Application of the coupling assay method to 14 porcine thyroid tissues}

By the assay method thus established, the coupling activity of microsomal TPO of 14 porcine thyroids was assayed, and the mean values are tabulated in Table 2. This Table also shows the activity of peroxidase assayed simultaneously, employing guaiacol of iodide as the substrate. The correlation between coupling assay and peroxidase assay was excellent, their correlation coefficients being in the range $0.80-0.95$.

\section{DISCUSSION}

The most frequently used procedures in the analysis of iodothyronines contained in $\mathrm{Tg}$ involve paper chromatography or t.l.c., ion-exchange chromatography and radioimmunoassay. Paper chromatography or t.l.c. has long

Table 2. Peroxidase activity and coupling activity of microsomal TPO in 14 porcine thyroids

\begin{tabular}{lll}
\hline & $\begin{array}{c}\text { Value } \\
\text { (mean } \pm \text { S.E.M.; } \\
n=14)\end{array}$ & \\
\hline Parameter & & Units \\
Peroxidase activity* & $9.14 \pm 3.61$ & $\mathrm{mGU} / \mathrm{mg}$ of protein \\
Guaiacol assay & $63.8 \pm 36.7$ & $\mathrm{mGU} / \mathrm{g}$ of tissue \\
Iodide assay & $1.58 \pm 0.59$ & $\mathrm{mIU} / \mathrm{mg}$ of protein \\
& $19.5 \pm 9.96$ & $\mathrm{mIU} / \mathrm{g}$ of tissue \\
Coupling activity $\dagger$ & $1.82 \pm 0.61$ & $\mathrm{CU} / \mathrm{mg}$ of protein \\
& $225.0 \pm 59.7$ & $\mathrm{CU} / \mathrm{g}$ of tissue
\end{tabular}

* The activity was determined by the ordinary method (Hosoya et al., 1985).

$\dagger$ The activity was determined as described in the text. 
been used, but it cannot be used for unlabelled iodoamino acids. Radioimmunoassay is very sensitive, but it requires radioiodine, facilities for radioactive material, and, moreover, requires separate analysis for each iodothyronine. The method using ion-exchange chromatography followed by detection of iodine with ceric arsenite seemed to be superior to other methods, but the band corresponding to $T_{3}$ tends to broaden when its $T_{3}$ content is low. Recently a number of researchers have reported analysis of these compounds by reversed-phase h.p.l.c. This has been due to the development of excellent columns for separation of the compounds in a short time. Most of these researchers were concerned with the analysis of iodothyronines in serum or bile and, to our knowledge, only two groups have reported a method for analysing iodothyronines from $\mathrm{Tg}$ (Alexander \& Nishimoto, 1979; Richheimer \& Jensen, 1986). In the latter analysis, the interference of other hydrophobic amino acids must be overcome. Alexander \& Nishimoto (1979) excluded the effect of hydrophobic amino acids by removing them by anion-exchange chromatography. However, we have attempted to find a way to analyse iodothyronines without taking such a step. This was to analyse iodothyronines in the presence of all amino acids derived from $\mathrm{Tg}$, taking advantage of calibration curves (not shown). It was confirmed, as shown in Table 1, that $\mathrm{T}_{4}$ values obtained by this analysis are in agreement with those of ion-exchange chromatography. In addition, this method can detect as little as 5 pmol of each iodothyronine, as evidenced from experiments shown in Fig. 3, compared with $50 \mathrm{nmol}$ of $\mathrm{T}_{4}$ in the case of ionexchange chromatography (Sorimachi \& Ui, 1974). The slight difference in the amount of $T_{3}$ detected between our method and their method is due to broadening of the $T_{3}$ band in the latter, since the $T_{3}$ content was very low. The sensitivity of radioimmunoassay is one order of magnitude higher than the present method, i.e. $0.4 \mathrm{pmol}$ for $\mathrm{T}_{4}$, but it requires much time and, moreover, cannot determine iodothyronines simultaneously. On the other hand, the present assay method can analyse three iodothyronines simultaneously in a short time, using a commonplace h.p.l.c. system without special attachments. This is certainly an important characteristic of the present assay.

Studies on the coupling reaction of iodotyrosine residues of Tg catalysed by purified animal TPO have been reported previously, but very few reports have been published concerning the coupling reaction catalysed by TPO of diseased human thyroid. Although Sugawara (1985) described a good assay for the coupling reaction catalysed by the TPO of human thyroid, we realized that there is much room for improvement for practical use. The main points we have improved in our assay method are as follows: (i) $\mathrm{Tg}$ used as the substrate was adjusted to have 41 iodine atoms per molecule by chemical iodination, on the basis of preliminary experiments; (ii) TPO solubilized with trypsin plus cholate from mitochondrial-microsomal fractions of human thyroids was directly used for the coupling reaction, but the content of TPO in the reaction mixture should be confined below $1 \mathrm{mGU}$; (iii) the amounts of DIT and glucose oxidase to be added to the reaction mixture were re-examined; (iv) $\mathrm{T}_{4}, \mathrm{~T}_{3}$ and $\mathrm{rT}_{3}$ were analysed simultaneously by h.p.l.c. and the sum of these values was used for the estimation of coupling activity. With these improvements it became possible to determine both coupling activity and peroxidase activity as well as protein and DNA contents with only $500 \mathrm{mg}$ of thyroid tissues.

The method for assaying coupling activity thus established was first applied to TPO from 14 porcine thyroids (Table 2). Although the coupling activity of porcine microsomal TPO was found to be distributed over a wide range, the mean values ( \pm S.E.M.) of the coupling activity obtained here may be useful for further studies of the activities of human TPO. The finding that there is a close correlation between coupling activity and guaiacol oxidation activity is also valuable, since $(a)$ the measurement of coupling activity in normal thyroid may be presumed from the values of guaiacol-oxidation activity and (b) a 'coupling' defect is expected if the coupling activity of human thyroid is unusually low compared with the mean values mentioned above.

We thank Dr. N. Suzuki and Dr. J. Sakurada (Chiba University) for helpful discussion and Mr. T. Narita (Gunma University) for the analysis of the iodine content of $\mathrm{Tg}$. Thanks are also due to Dr. J. Takamatsu (Osaka Medical College) for supplying Graves'-disease thyroid tissues. This study was supported in part by a grant-in-aid for Scientific Research of the Ministry of Education, Science and Culture of Japan.

\section{REFERENCES}

Aibara, S., Yamashita, H., Mori, E., Kato, M. \& Morita, Y. (1982) J. Biochem. (Tokyo) 92, 531-539

Alexander, N. M. \& Nishimoto, M. (1979) Clin. Chem. 25, $1757-1760$

DeGroot, L. J. \& Niepomniszcze, H. (1977) Metabolism 26, 665-718

Hearn, M. T. W., Hancock, W. S. \& Bishop, C. A. (1978) J. Chromatogr. 157, 337-344

Hosoya, T. \& Morrison, M. (1967) J. Biol. Chem. 242, 2828-2836

Hosoya, T., Sato, I., Hiyama, Y., Yoshimura, H., Niimi, H. \& Tarutani, O. (1985) J. Biochem. (Tokyo) 98, 637-647

Kohno, Y., Hiyama, Y., Shimojo, N., Niimi, H., Nakajima, H. \& Hosoya, T. (1986) Clin. Exp. Immunol. 65, 534-541

Ohtaki, S., Nakagawa, H., Nakamura, S., Nakamura, M. \& Yamazaki, I. (1985) J. Biol. Chem. 260, 441-448

Richheimer, S. L. \& Jensen, C. B. (1986) J. Pharmacol. Sci. 75, 215-217

Sorimachi, K. \& Ui, N. (1974) J. Biochem. (Tokyo) 76, 39-45 Sugawara, M. (1985) J. Clin. Endocrinol. Metab. 60, 1069-1075 Taurog, A., Dorris, M. \& Lamas, L. (1974) Endocrinology (Baltimore) 94, 1286-1294

Yoshimura, H., Ito, K., Tarutani, O. \& Hosoya, T. (1988) Acta Endocrinol. (Copenhagen) 118, 147-153 